\title{
表面処理鋼板製造工場における 包装会社とのSCMの構築
}

\author{
山本 彰*・山本 賢治*・武田 和宏*2・柘植 義文*3
}

Construction of Supply Chain Management with Packing Companies in the

Surface Treatment Steel Manufacturing Plant

Akira Yamamoto, Kenji Yamamoto, Kazuhiro TaKeda and Yoshifumi Tsuge

Synopsis : Kudamatsu plant projected the three-year mid term managerial program in 2002, promoting the integration and reorganization of subsidiary companies and reviewing the material and supplemental material procurement operation.

As a part of this program, manufacturing for packing material and packing operations, which work had been so far divided into 6 subsidiaries, were integrated and entrusted to a newly founded single company. Then we tied up S.C.M. (Supply Chain Management) with it.

Practically, packing operation was not involved in production control system. That is the reason some troubles frequently occurred, such as delivery delays due to the packing stagnation and the conflicting imbalance between the production and the packing operational flow.

Therefore, along with S.C.M. construction, packing operation was included into the production control system in which overall reformation was being made at the time.

Our purpose was to establish a system of manufacturing and packing section that can link together in the time scheduling.

Integration and reorganization of subsidiary companies started in October 2002. Packing control system started in October 2004, and now demonstrating noticeable results such as labor saving in packing worker, improvement of material flow, packing productivity, and delivery date achievement level.

Key words: production control; scheduling system; packing; supply chain management; theory of constraints.

\section{1. 緒言}

東洋鋼鈑下松工場は，2002年から 3 ケ年の中期経営計画 を策定しグループ会社の統合・再編と資材・副資材調達管 理の見直しを推進している。その一環として6社で分担し ていた包装作業及び包装資材製作業務を統合して新会社に 一括委託し，同社との間に $\mathrm{SCM}^{1,2)}$ (Supply Chain Management)を構築することとした。

従来，当社の包装作業については生産管理システムの範 囲外となっており, 包装関係グループ会社とのシステム連 携が不十分であるため包装前に仕掛が滞留して納期遅れを 招いたり，製品化工程と包装能力のアンマッチが起こる等 の不具合が問題となっていた。

今回の SCM構築にあたっては，同時期に $\mathrm{APS}^{3,4}(\mathrm{Ad}-$ vanced Planning and Scheduling)を導入して再構築を推進し てきた下松工場の生産管理システムに包装工程を組込むこ とにより，製造工程と包装工程が連結してスケジューリン グできる体制を目指した。

包装関係グループ会社の統合・再編については 2002 年
の10月からスタートし, 次いで包装予定立案システムは 2004 年 10 月から運用開始しており，導入効果として包装 要員の省力化, 包装仕掛の削減, 包装リードタイムの短縮 及び納期精度の向上が図られたので報告する。

\section{SCM 構築の経緯}

当社を取巻くSupply Chainについて Fig. 1に示す。当社 の主力製品であるブリキ等表面処理鋼板は, 高炉メ一カ一 より購入した熱延鋼板を冷間圧延し，メッキやラミネート 等の表面処理を施して製造される。近年PETボトルの急激 な浸透により従来の主力製品であった飲料缶用材料に対す る需要はシュリンクする傾向にあり, 電子機器・電池向け 材料の生産比率が高くなってきている。これらの製品は景 気動向による需要変動が大きく, 需要家からの短納期の要 求も綮しい。そこで生産変動にフレキシブルに対応でき, 短いリードタイムで製品を製造できる生産体制の構築を進 めることとなった。

そのために下記の4ステップにてSCMを構築していく 


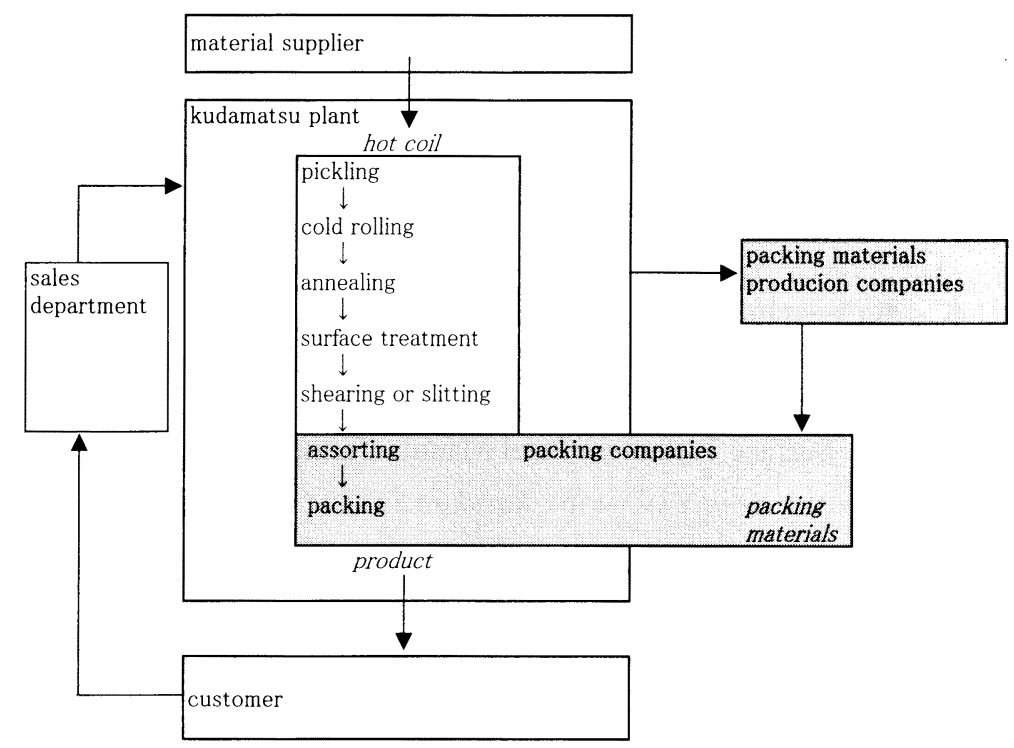

Fig. 1. Supply chain of production and packing.

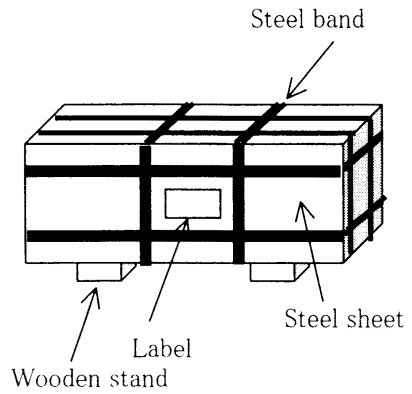

Sheet packing

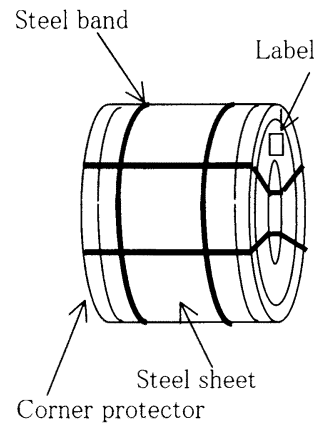

Coil packing
Fig. 2. Specification of packing.

こととした。

(1) 焼鈍工程に代表される工場内のボトルネック工程の強 化 ${ }^{5)}$

(2) 包装関係グループ会社との SCM 構築。

(3) 本社営業部門および一部需要家とのSCM 構築。

(4) 材料メーカーとのSCM 構築。

このうち、(1)については既に完了しており，(2)ついて は今回取り組んだ事例である。(3)と(4)については今後実施 する予定である。

\section{3. 包装作業概要}

当社製品の包装形態はシート包装とコイル包装に大別さ れ，現在はコイル包装が $70 \%$ を占めている。代表的な包 装の仕様を Fig. 2 に示す。シート包装は裁断ラインに直結 して流机作業で行われる。コイル包装についてはスリッ ティングラインの後方にある5 個所の包装場に運搬して, 午前 8 時から 24 時までの 16 時間で包装作業を実施する。 包装作業の種類と担当会社を Table 1 に示寸。
Table 1. Integration of packing and assorting companies.

\begin{tabular}{|ll|l|}
\hline & before OCT. 2002 & after OCT. 2002 \\
\hline assorting of products & toyo kohan & new company \\
\hline packing of sheet products & campany A & new company \\
\hline packing of coil products & company B & new company \\
\hline packing of hoop products & company C & new company \\
\hline produce of metal packing materials & company D & company D \\
\hline produce of wooden packing materials & company E & company D \\
\hline
\end{tabular}

包装に必要な包装資材は構外の関係会社が製作して1日 1 回納入する。包装資材製作会社には事前に 2 週間分の当 社の生産計画を伝送して大まかな資材製作計画を策定させ る。正式な注文は毎日午前中に包装仕掛をもとに必要な資 材の寸法を実測して包装資材製作会社に発注し, 当日午後 には当社に資材を納入する体制である。

\section{4. 生産・物流上の課題}

改善前の包装作業においては, 複数のグループ会社が作 業を細分化していること, 包装作業の生産管理システムが 無いことなどに起因する下記のような課題があった。

（1）シート包装とコイル包装が別会社のため, 生産量 の変動に伴う要員の手配が流動化できず, 特に間歇運転作 業の多いシート包装要員に手叙りが出ていた。

（2）コイル包装の生産性が低く，包装前仕掛が滞留し て包装場を压迫し, 置場不足からスリッティングラインを 停止する事態も起きていた。

（3）コイル包装のリードタイムが長く, 包装待ちで納 期遅れになる事が多く, 営業から包装作業に対する納期管 理機能強化を求められていた。 


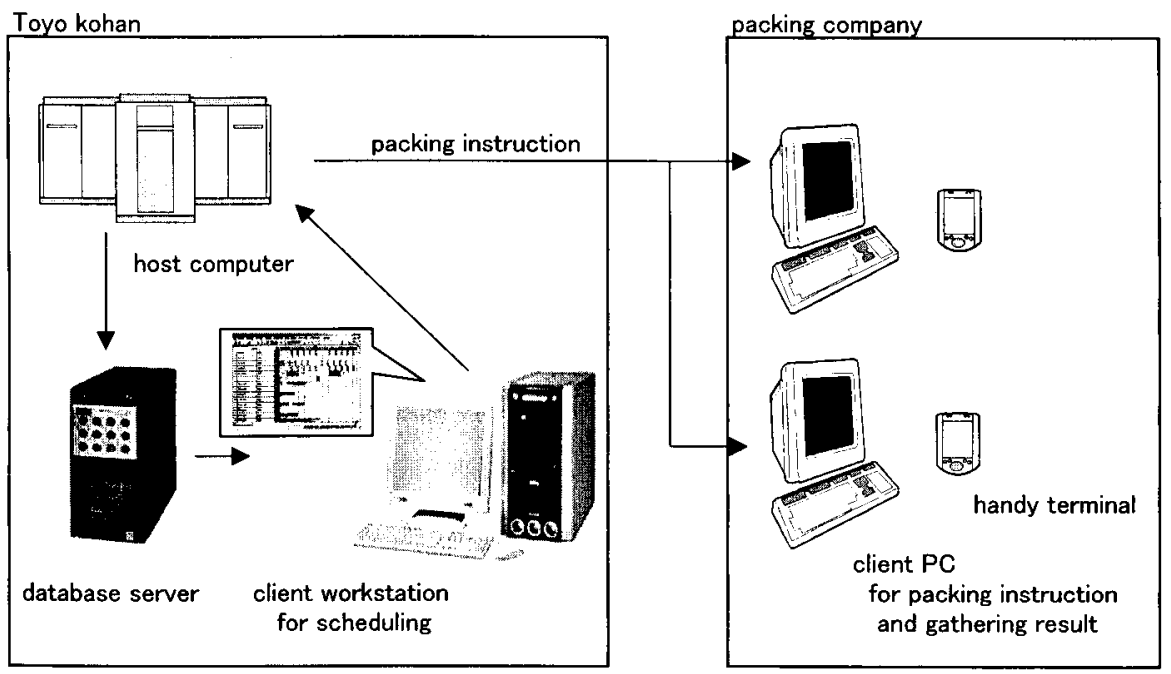

Fig. 3. Specification of computer system.

（4）包装作業の生産管理システムが無いため包装に対 する作業指示ができず，入庫予定の納期回答精度が低かっ た。

（5）正確な包装作業予定が無いため包装資材の事前発 注精度が低く，手配した資材と実際に製品化した仕掛コイ ルのずれが生じて資材納入遅れによる包装待ちが頻発し た。

\section{SCM 構築}

前述した課題を解決するため, 包装関係グループ会社の 統合・再編と包装予定立案システムの構築をメインにした SCMを推進することとなった.

第1に裁断ライン，スリッティングラインの運転および 製品検定作業と包装作業を全て1会社に統合し，新会社を 2002年 10月に設立した。また包装資材製作会社について も木材関係と金属関係に分かれていたものを 1 社に統合し た。Table 1に統合後の分担を示す。

包装作業の組織についてはシート包装係とコイル包装係 に大別するが，多能工化を進めてお互いに応援可能にして 生産品種構成の変動に柔軟に対応できる組織づくりを目指 すこととした。

第2に包装予定立案システムを構築して工場全体の一貫 した生産計画システムに組みいれることとした。当工場で は2002年 10 月から TOC $^{6)}$ (Theory Of Constraints)をべース にした生産計画立案システムを運用していたが，このシス テムを改造して包装作業のスケジューリングができるよう にした。このシステムを用いて包装関係グループ会社への 情報伝達を迅速に行い，生産計画と連携の取れた包装資材 の供給と包装要員の手配を可能にし，グループ会社を含め た物流の最適化を図った。

\section{6. 包装予定立案システム}

包装予定立案システムのハードウェア構成を Fig. 3に示 す。包装予定立案システムは生産管理部門に設置されたク ライアントワークステーションに拈て 1日1回実行され る。このシステムに必要な操業データはホストコンピュー タからデータベースサーバにダウンロードされ，立案され た包装予定データはデータベースサーバからホストコン ピュータにアップロードされる。各包装場に端末とハン ディターミナルを設置して生産計画部門からの包装作業指 示を包装作業者に伝達でき，さらに包装実績が収集できる ようにした。

包装予定立案システムに必要な機能は次の 4 点である。 これらの機能は最終的に包装工程の作業指示をする為に， (1) (4)の順番に実行される。システムのロジックの流れを Fig. 4 に示军。

(1) 包装場への振分け

(2) 包装能力計算

(3) 包装作業指示

(4) 包装実績入力

包装予定立案システムには毎朝 5 時現在の工場内仕掛コ イルのデータがインプットされ, 各仕掛コイルが持つ通過 工程の順にフォワードで作業予定をシミュレートして流し 計算をしていく。流し計算の例を Fig. 5 に示す。裁断ライ ンまたはスリッティングラインが終わった仕掛コイルは製 品の仕様で定められた質量に分割されて包装前製品とな る。その製品の品種と包装仕様，および通過工程の最終ラ インの号機により包装場が決定される。Fig. 5で示すよう に電気めっきぶりきのコイル包装仕様であればNo. 4 ス リッティングラインで製品化されてNo. 5 包装場で包装さ れる。包装予定立案システムは包装場每に4週間分の包装 前製品の作業順列を作成する。 


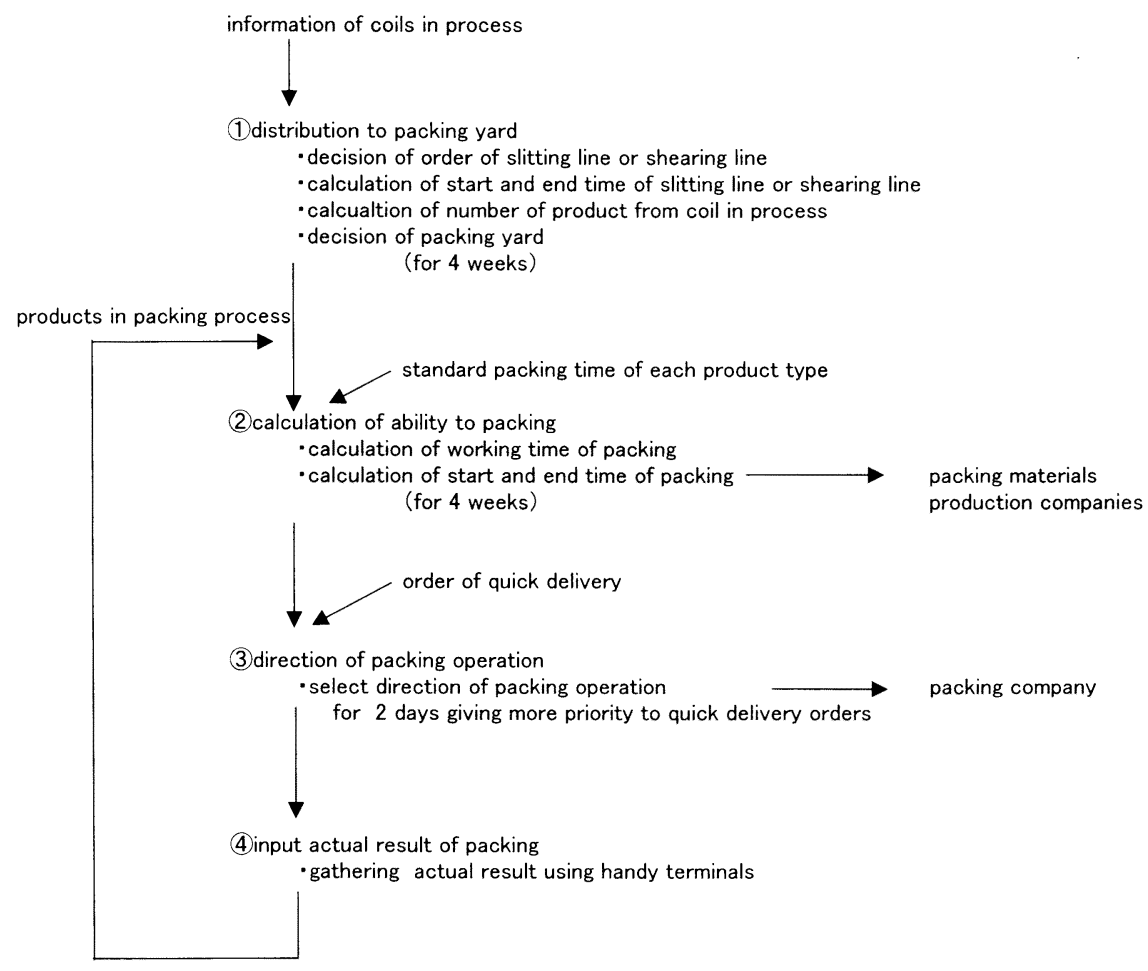

Fig. 4. Logical flow of packing control system.

\begin{tabular}{|c|c|c|c|c|}
\hline \multirow[t]{3}{*}{$\langle$ PROCESS $\rangle$} & \multirow[t]{2}{*}{$\langle$ COIL IN PROCESS $\rangle$} & \multirow[t]{2}{*}{ 〈FACILITY ALLOCATION〉 } & \multicolumn{2}{|r|}{$\begin{array}{l}\text { as of } 1 \text { st April } \\
\text { RK TIME }>\end{array}$} \\
\hline & & & START TIM & END TIME \\
\hline & $\begin{array}{l}\text { COIL No. X-0001 WT:15,000Kg } \\
\text { Product WT:6,700Kg electolytic tinni }\end{array}$ & & & \\
\hline pickling & COIL No. X-0001 WT:14,500Kg & No.2 pickling line & $2005 / 4 / 28: 00$ & $2005 / 4 / 28: 15$ \\
\hline cold rolling & COIL No. X-0001 WT:14,100Kg & No.2 tandem mill & $2005 / 4 / 3 \quad 10: 10$ & $2005 / 4 / 310: 18$ \\
\hline$\underset{\downarrow}{\operatorname{annealing}}$ & COIL No. X-0001 WT:14,000Kg & No. 3 continuous annealing line & 2005/4/4 18:20 & 2005/4/4 18:45 \\
\hline temper rolling & COIL No. X-0001 WT:13,800Kg & No.3 temper mill & $2005 / 4 / 620: 11$ & $2005 / 4 / 620: 38$ \\
\hline$\underset{\downarrow}{\text { surface treatment }}$ & COIL No. X-0001 WT:13,700Kg & No.3 electolytic tinning line & $2005 / 4 / 80: 45$ & $2005 / 4 / 81: 11$ \\
\hline shearing or slitting & $\begin{array}{l}\text { COIL No. X-0001 WT:,6,700Kg } \\
\text { COIL No. X-0001-1 WT:,6,700Kg }\end{array}$ & No.4 slitting line & $\begin{array}{l}2005 / 4 / 103: 25 \\
2005 / 4 / 103: 56\end{array}$ & $\begin{array}{l}2005 / 4 / 103: 55 \\
2005 / 4 / 104: 25\end{array}$ \\
\hline packing & $\begin{array}{l}\text { Product No. 0410-1 WT:6,700Kg } \\
\text { Product No. 0410-2 WT:6,700Kg }\end{array}$ & No.5 packing yard & $\begin{array}{l}2005 / 4 / 1020: 10 \\
2005 / 4 / 1020: 25 \\
\end{array}$ & $\begin{array}{l}2005 / 4 / 1020: 25 \\
2005 / 4 / 1020: 40 \\
\end{array}$ \\
\hline
\end{tabular}

Fig. 5. Example of simulation from pickling to packing.

包装仕様によって包装作業の難易度が異なるため, 品 種・包装仕様をキーにして1梱包あたりの標準作業時間を 計測してテーブルに設定している。包装予定立案システム はこのテーブルを検索して包装前製品 1 梱包ごとに作業時 間を算出して1日あたりの各包装場の作業予定を立案す る。Fig. 5 の例では電気めっきぶりきのコイル包装仕様で は1梱包あたり 15 分の包装作業時間がテーブルに設定され ており，15tの仕掛コイルから製品単重 $6.7 \mathrm{t}$ の製品が2梱 包出来ることから, 合計で 30 分の包装作業時間がかかる ことになる。この計算も 4 週間先まで行うが, その内 2 週 間分を包装資材製作会社に伝送し，包装材の事前手配に活 用する。また 4 週間先までの包装作業予定データは包装場 と製品倉庫のキャパシティを予測する資料として活用され
る。

生産が終了していないが出荷の予定が決まっている受注 契約品については別途ホストシステムにおいて特急包装指 示を生産計画担当者がインプットし，出荷に間に合うよう な包装終了期限を包装作業者に指示できるようになってい る。この特急包装指示データは包装予定立案システムにも 入力されて包装予定を立案する際に優先的に割付られるよ うになっている。

包装予定立案システムは直近2 日分の包装作業予定を抽 出して, ホストコンピュータに送信する。ホストシステム では包装場単位に包装作業順を記入した包装作業予定表を 作成し，包装作業者はこれに従って作業を行う。

包装作業が終了すると製品に添付しているラベル検定票 
のバーコードをハンディターミナルで読み取り，包装実績 を上げる。これにより包装が終わった製品は包装仕掛から 削除される。

包装作業が終了せずに残った包装前製品は翌日の計画立 案時に包装前製品データとしてインプットされ, 再度包装 予定を立案されることになる。

\section{7. 成果}

包装関係グループ会社の統合・再編によって誕生した新 包装会社は 2 年を経過して要員の多能工化が順調に進み, 変動する生産計画に対してフレキシブルに配置が変えられ る組織に成長している。包装予定立案システムで先の包装 予定を事前に把握できるため, きめ細かな包装要員の配置 ができるようになった。Table 2 に統合前後の生産量と包装 要員を示す。シート包装については生産量は変わらず6名 を省力し，コイル包装は生産量が1.4倍に増加しても2名 増のみで対応し 1 名当りの生産性は1.3倍に向上している。

また，Table 3 に示すように生産性の向上に付随して包装 仕掛量も従来の $1 / 3$ に大幅に減少しており，包装リードタ イムも半減している。営業の特急要請についても包装作業 員に漏れなく伝達できるようになり包装遅れ起因の納期遅 延が防止できるようになった。

生産計画部門で包装作業予定を作成するため，急ぐ物を 優先的に作業させる事が可能になり，納期管理機能が強化 されてきた。包装作業予定と包装資材発注システムをリン クすることで包装資材手配も省力化でき精度が向上してい る。

\section{8. 結言}

個別最適から全体最適へ視点を移したグループ戦略の見 直しにより，包装グループ会社の統合・再編と当社と包装 関係グループ会社のSCMの構築について紹介した。
Table 2. Comparison of production and number of packing workers.

\begin{tabular}{|l|cc|}
\hline & 2002 & 2004 \\
\hline amount of sheet products [number/d] & 561 & 565 \\
\hline workers for sheet packing [man] & 33 & 27 \\
\hline productivity of sheet packing[number/d/man & 17 & 21 \\
\hline amount of coil products [number/d] & 460 & 650 \\
\hline workers for coil packing [man] & 23 & 25 \\
\hline productivity of coil packing[number/d/man] & 20 & 26 \\
\hline
\end{tabular}

Table 3. Comparison of amount of goods in process and average lead time.

\begin{tabular}{|l|r|r|}
\hline & 2002 & 2004 \\
\hline Amount of product in process $\left[\right.$ ton $_{-}{ }_{-}$ & 3,400 & 1,300 \\
\hline Average lead time [d] & 4.7 & 2.2 \\
\hline
\end{tabular}

包装工程は納期管理において客先の納期を遵守できるか どうかを左右する重要な工程である。従来当社においては 生産計画の範囲外となっていた包装工程を上流工程と一貫 して計画立案できるようになった事で顧客サービスも向上 しつつある。

今後は材料メーカー, 商社, 顧客にまでサプライチェー ンの輪を広げていき全社的な SCMを完成させていく。

\section{文献}

1) Y.Umezawa: Communications Operation Res. Soc. Jpn., 48 (2003), No. 12,879 .

2 ) H.Matsuo: Communications Operation Res. Soc. Jpn., 48 (2003), No. 12,886 .

3 ) K.Narimatsu: Communications Operation Res. Soc. Jpn., 49 (2003), No. 12,576 .

4 ) S.Nomoto: Communications Operation Res. Soc. Jpn., 49 (2003), No. 12,589 .

5 ) A.Yamamoto, K.Yamamoto, K.Takeda and Y.Tsuge: Tetsu-toHagané, 91 (2005), 66.

6 ) K.Funaki: Communications Operation Res. Soc. Jpn., 49 (2003), No. 12,687 . 